\title{
Coronavirus Pandemic (COVID-19): A Survey of Analysis, Modeling and Recommendations
}

\author{
Tehmina Amjad $^{\text {a }}$, Ali Daud ${ }^{\mathrm{b}}$, Malik Khizar Hayat ${ }^{\mathrm{c}}$, Muhammad Tanvir Afzal ${ }^{\mathrm{d}}$, Hussain Dawood ${ }^{\mathrm{e}}$ \\ ${ }^{a}$ Department of Computer Science and Software Engineering, International Islamic University, Islamabad, Pakistan \\ ${ }^{b}$ Department of Information Systems and Technology, College of Computer Science and Engineering, University of \\ Jeddah, Jeddah, Saudi Arabia \\ ${ }^{\mathrm{c}}$ Department of Computer Science, Quaid-i-Azam University, Islamabad, Pakistan \\ ${ }^{\mathrm{d}}$ Capital University of Science and Technology (CUST), Islamabad, Pakistan \\ ${ }^{e}$ Department of Computer and Network Engineering, College of Computer Science and Engineering, University of \\ Jeddah, Jeddah 23890, Saudi Arabia \\ tehminaamjad@iiu.edu.pk; adaud@uj.edu.sa; khizerhayat92@gmail.com; mafzal@cust.edu.pk; hdaoud@uj.edu.sa \\ Corresponding author: Tehmina Amjad (e-mail: tehminaamjad@iiu.edu.pk)
}

\begin{abstract}
COVID-19 has created anxiety not only in individuals but also in health organizations, and countries worldwide. Not a single industry is left un-influenced and loss is being estimated in billions of dollars. The widespread of this pandemic disease has challenged researchers all over the world. Some of the researchers are working to invent its cure while, others are applying computing technologies to stop its spread, by analyzing and identifying patterns for prediction and forecasting. This is by no doubt the hottest area of research for the last 100 years. This survey has targeted the research published in computing sub-domains to combat the pandemic. The survey has clustered the scientific efforts into logical groups: surveillance, metrological effects, social media analytics, image processing and business and economy, analysis and modeling. It will serve as a leading source for the followings: researchers who want to identify what has been achieved in different computing sub-domains, those who need fresh authenticated datasets openly accessible for different research contexts and what are future directions in this area of research. The findings of analysis and modeling can be also useful for government agencies who want to set priorities and formulate policies.
\end{abstract}

Keywords: Coronavirus Pandemic (COVID-19); Analysis; Modeling; Recommendations; Surveillance; Social Media Analytics; Meteorological Effects; Image Processing; Business and Economy

\section{Introduction}

Coronavirus Pandemic (COVID-19), initially called Novel Coronavirus Disease has created social, psychological, and economic impacts on humanity. Billions of dollars were lost due to business shut down, cancellation of events, cancellation of traveling trips, supply chain, manufacturing, and partial or complete lockdowns. Schools, colleges, and universities are closed and learning is affected badly. People are losing their jobs or in some cases, they are not paid to meet their daily expenses especially in developing countries (Ahani and Nilashi 2020). Such huge impacts have emerged as chaos worldwide and have challenged the scientific community to find out the ways 
of getting rid of this pandemic disease and to propose remedying measures to stops its spread (Fetzer et al. 2020).

The efforts of scientists can be broadly categorized into two classes such as (1) ones who are trying to find out the cure of the disease by studying the virus itself in microbiological labs (Du Toit 2020), and (2) the ones who are using computing technology to find hot spots of patients, studying migration and disease diffusion patterns, identifying important measures, and parameters to quickly recommend the areas in which the disease may be spread in near future (Elmousalami and Hassanien 2020). This survey paper is based on the research published by the later ones.

To fight against this pandemic disease, the computing community has contributed in many different dimensions and have come up with great research ideas. It was itself not a trivial task to collect, organize and present all of the important work that could help the following stakeholders: (1) Governments and health organizations who want to set policies, (2) one who wants to find out the dimensions in which the research efforts have emerged, subsequently what has been achieved and what left as a challenge to address, (3) who wants to identify the future directions and really serious to come up with seminal nature work in the area to save the humanity, and (4) who wants to identify which datasets are available, what are their parameters, authenticity, coverage, and freshness of data.

Based on the critical analysis of the literature published in the first quarter of 2020, this survey has placed the studies published related to the computing aspects of coronavirus into the five classes as shown in Figure 1. The categories are: (a) surveillance, (b) meteorological effects, (c) social media, (d) image processing, and (e) business and economy.

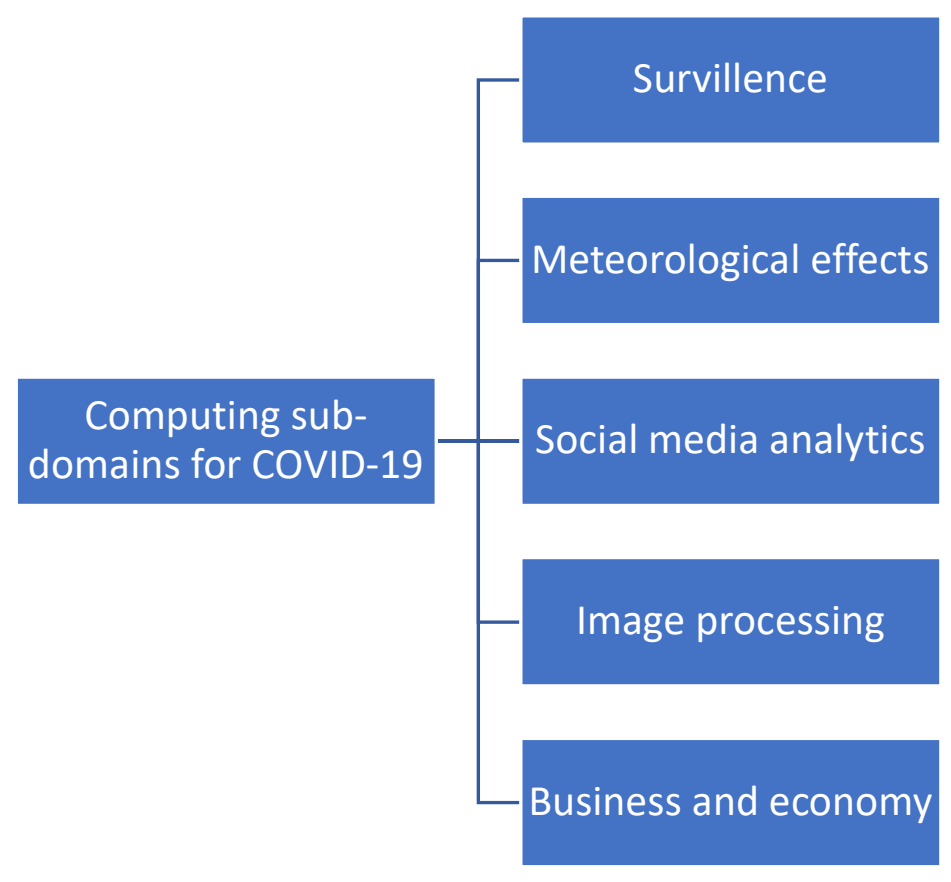

Figure 1: Categorization of methods that study coronavirus 
The first category discussed in this survey is Surveillance. The scientific community has exploited different features such as the number of reported cases, number of fatalities, time taken from exposure to when symptoms start to appear, local case or imported case, and migration data. Based on different mathematical and statistical models, the following important discoveries are tried to be made for the pandemic disease such as (1) identification of minimum social distance, (2) forecasting the spread of coronavirus, (3) models for early prediction, (4) forecasting the seriousness of situation, (5) prediction of the spread of the virus, (6) prediction of the peak and end of the pandemic, (7) effect of asymptotic infections, and (8) coronavirus evolution. To answer such questions is important to make a proper policy to avoid the further spread of the disease (Reyad 2020; Brandenburg 2020; Jia et al. 2020).

The second category covered in this survey is meteorological effects. In this category, the effect of different meteorological variables is studied, which is then helpful for forecasting and prediction strategies. Such strategies lead to come up with good strategies and policies to stop the spread of the disease. The parameters studied by the scientific community are: wind, temperature, humidity, air temperature, relative humidity, wind speed, visibility on the outbreak, precipitation, and rate of COVID-19 spread (B. Chen et al. 2020; Oliveiros et al. 2020).

The third category encapsulates studies related to social media analytics. Some researchers have identified that social media can be helpful in quick identification and forecasting of different COVID-19 statistics. However, social media data needs to be taken with caution as fake news prevails with high velocity and can make more damages than expected (Cinelli et al. 2020; Ahani and Nilashi 2020).

The fourth category explained in this survey is related to the studies on image processing. The image processing has been applied successfully to study the effect and spread of the disease. Images of CT Scan and Lungs X-rays are processed for analysis, modeling and recommendations.

The fifth category is the economy and business. Many scientists have studied the global economy and business using the Baltic Exchange Dry Index (BDI) and Structural Vector Auto Regressive (S-VAR) model. Furthermore, the Gross Domestic Product (GDP), Stock exchange studies, health, trade, travel, agriculture, industry, and various types of the market have been studied (Yilmazkuday 2020; Albulescu 2020; Nguyen 2020).

Subsequently, this paper has identified datasets available for researchers related to surveillance, meteorological effect, social media analytics, image processing, and economy and business. Different dataset parameters have been focused such as dataset statistics, features, and dataset duration. The paper ends with highlighting future directions and current challenges.

In all, the major contributions made in this study are summarized as follows:

- Highlights the important dimension in which research community has worked for COVID19 and provides a chronological study of existing methods that can provide a roadmap to extract useful insights for the research community

- Provides a classification of methods based on research published in the computing subdomains and identifies key features to study the semantics of the problem

- Provides insights about standard COVID-19 datasets 
- Provides useful recommendations and directions for future research

Here, we also include a summary table (Table 1) that shows the methods that have been published from February 2020 to April 2020 regarding the outbreak.

Table 1: The summary of methods covered in the survey

\begin{tabular}{|c|c|c|c|c|c|}
\hline & Surveillance & $\begin{array}{l}\text { Meteorological } \\
\text { Effect }\end{array}$ & $\begin{array}{l}\text { Social Media } \\
\text { Analytics }\end{array}$ & $\begin{array}{l}\text { Image } \\
\text { Processing }\end{array}$ & $\begin{array}{l}\text { Business and } \\
\text { Economy }\end{array}$ \\
\hline February & $\begin{array}{l}\text { (Brandenburg } \\
\text { 2020), } \\
\text { (Nesteruk } \\
\text { 2020), (Y.-C. } \\
\text { Chen et al. } \\
\text { 2020), (Prasse et } \\
\text { al. 2020) } \\
\text { (Gamero, } \\
\text { Tamayo, and } \\
\text { Martinez- } \\
\text { Roman 2020) }\end{array}$ & & $\begin{array}{l}\text { (Ahani and } \\
\text { Nilashi 2020) }\end{array}$ & & $\begin{array}{l}\text { (McKibbin and } \\
\text { Fernando 2020) }\end{array}$ \\
\hline March & $\begin{array}{l}\text { (Reyad 2020), } \\
\text { (Shim et al. } \\
\text { 2020), } \\
\text { (Elmousalami } \\
\text { and Hassanien } \\
\text { 2020), (Jia et al. } \\
\text { 2020), (Zhong } \\
\text { et al. 2020), } \\
\text { (Fong et al. } \\
\text { 2020a), (Fong et } \\
\text { al. 2020b) }\end{array}$ & $\begin{array}{l}\text { (B. Chen et al. } \\
\text { 2020), (Oliveiros } \\
\text { et al. 2020), (Ma et } \\
\text { al. 2020) }\end{array}$ & $\begin{array}{l}\text { (Cinelli et al. } \\
\text { 2020), (Nelson } \\
\text { et al. 2020), } \\
\text { (Qin et al. } \\
\text { 2020) }\end{array}$ & $\begin{array}{l}\text { (S. Wang et al. } \\
\text { 2020), } \\
\text { (Hemdan, } \\
\text { Shouman, and } \\
\text { Karar 2020), } \\
\text { (Narin, Kaya, } \\
\text { and Pamuk } \\
\text { 2020) }\end{array}$ & $\begin{array}{l}\text { (Yilmazkuday } \\
\text { 2020), } \\
\text { (Albulescu } \\
\text { 2020), } \\
\text { (Fernandes } \\
\text { 2020), (Gong et } \\
\text { al. 2020), } \\
\text { (Nguyen 2020), } \\
\text { (Evans 2020), } \\
\text { (Atkeson 2020), } \\
\text { (Toda 2020) }\end{array}$ \\
\hline April & $\begin{array}{l}\text { (Zheng, Zi-xia, } \\
\text { and Zu-yao } \\
2020 \text { ) }\end{array}$ & $\begin{array}{l}\text { (Tosepu et al. } \\
\text { 2020), (J. Wang et } \\
\text { al. 2020), } \\
\text { (Shokouhi et al. } \\
2020,19)\end{array}$ & (Saire 2020) & $\begin{array}{l}\text { (Rajinikanth et } \\
\text { al. 2020), } \\
\text { (Afshar et al. } \\
\text { 2020), (Wu et al. } \\
\text { 2020), (X. Chen, } \\
\text { Yao, and Zhang } \\
\text { 2020), (Oh, } \\
\text { Park, and Ye } \\
2020)\end{array}$ & $\begin{array}{l}\text { Alvarez, } \\
\text { Argente, and } \\
\text { Lippi 2020) }\end{array}$ \\
\hline
\end{tabular}

\section{Concepts and Terminologies}

An epidemic is a widespread appearance of a disease that is infectious, in a community at a particular time. The human race has already faced several epidemics including AIDS, Avian Flu, SARS, MERS, Ebola, Zika (Reperant and Osterhaus 2017). An epidemic is declared as a Pandemic when it affects even a wider range of areas.

Novel coronavirus disease (COVID-19), is a pandemic that has emerged across the globe and it was initiated from Wuhan, which is the capital of the Hubei province of China, in December 2019. It belongs to the family of coronaviruses that have already appeared in past namely, severe acute 
respiratory syndrome coronavirus (SARS-CoV) in 2003 and Middle East respiratory syndrome coronavirus (MERS-CoV) in 2012 (Kwok et al. 2019).

By Surveillance, in this survey, we refer to the methods that are using the day to day statistics of the parameters related to the COVID-19 pandemic, (for example, reported cases, confirmed cases, total deaths, total recovered cases). These are the methods that are providing analysis, which is either visualizing these statistics or are applying some statistical or mathematical models on the data to predict the future outcomes related to the disease.

Meteorological effect refers to the study the impact of environmental variables like wind, temperature, humidity. Currently, in the context of COVID-19 pandemic, people are extremely interested in knowing the impact of these variables on health conditions, specifically on death around the globe.

Social media analytics includes websites through which people are connected. they can share their thoughts, show their liking and disliking, and many more. For instance, the Twitter social network provides a lot of research challenges related to sentiment analysis of different emotional themes like fear, gratitude, stress, or depression. This type of sentiment analysis is very useful during the time of pandemic spread to make policies, take timely decisions, and be updated with the dynamics of this disease.

Image Processing means the investigation of the objects in an image and performs some procedures to enhance the image. Medical images may have different types of anomalies such as noise or blur. To avoid the erroneous diagnosis, these anomalies should be reduced by preprocessing steps to enhance the quality of an image. Then the image can be further used to diagnose the exact problem. In the end, images are classified as positive and negative for a specific disease. The severity of the disease also can be classified as low, high, and mild. Here all possible manipulation of imaging is considered, which is mainly divided into two parts: first, image processing, and second, image classification. Currently, X-ray images and CT Scans of lungs are being analyzed to detect the severity of COVID-19 impact on human health.

Business and economy are the backbones of every country. It is the process of selling and buying products in a way that one can gain economic power over other countries. COVID-19 has a great impact on both business and economy, specifically, oil business-based economies are hit by a thunder and, oil trade crashed like never been before, especially due to canceled flights and industry lockups. The government these days needs real analysis and recommendations to come up with timely decisions and policies to control the situation and save their economies.

\section{Coronavirus Pandemic (COVID-19) Computing Sub-Domains}

The novel COVID-19 was identified in Wuhan, China, at the end of the previous year. Due to the rapid increase in the COVID-19 cases, several countries implemented the lockdown methodology to counter the deadly effects of the virus. Several efforts have been made to investigate the COVID-19 effect and its impact by the computing eye. Based on the detailed analysis of the literature published in the first quarter of 2020, this survey categorizes the studies published related 
to the computing aspect of coronavirus into the five classes. Here in this section, we discuss them in detail.

\subsection{COVID-19 Surveillance}

With the emergence of around 7000 infectious cases from China and several cases from other countries including Thailand, Japan, United States of America, and South Korea - World Health Organization (WHO) declares coronavirus outbreak as a Public Health Emergency of International Concern (PHEIC). Considering the seriousness of the disease, several researchers started the surveillance of the statistics of the disease to predict the reproduction rate and to find recommendations to limit its spread. The current number of reported cases as on April 22, 2020, is $2,559,991$ across 210 countries around the world.

According to the WHO, the novel COVID-19 has been spread in more than 195 countries, worldwide. However, the first COVID-19 case reported in the Middle East Arab region was in the United Arab Emirates (UAE) (Reyad 2020). The authors compared the previous two well-known epidemics - the Severe Acute Respiratory Syndrome (SARS) and the Middle East Respiratory Syndrome (MERS) with the current COVID-19. The death rate was $10 \%$ and $35 \%$ for SARS and MERS, respectively. Several efforts exist to forecast the growth rate of COVID-19 (Brandenburg 2020; Li et al. 2020). However, according to the current COVID-19 stats by the Worldometers ${ }^{1}$, the death rate is $0.002 \%$ in Saudi Arabia. In the overall Arab region, Qatar is leading the total number of COVID-19 cases followed by Bahrain, and Saudi Arabia (Reyad 2020).

Experimentation conducted by (Brandenburg 2020) shows that the relationship between the number of reported cases and the number of fatalities is quadratic, not exponential and the same relationship is expected in the upcoming one to two months. The reproduction rate of coronavirus disease in South Korea was studied by (Shim et al. 2020). The authors analyzed the data made available by the Korea Centers for Disease Control and Prevention. They studied the confirmed cases, and the time when symptoms started to appear for the first 28 reported cases. They also characterized that cases are transmitted locally or imported.

A study to statistically analyze the migration data of Wuhan and COVID-19 was conducted by (Zheng, Zi-xia, and Zu-yao 2020). The authors studied the number of infected people in Wuhan. The authors discovered that the mean and median of the diagnosis rate of cities of Hubei province was lower as compared to the cities outside Hubei province.

(Elmousalami and Hassanien 2020) recommended the widespread application of all forms of social distancing measures in affected regions. The recommendations were based upon the findings of their experimentations in which time series models and the mathematical formulation was used to forecast the spread of coronavirus on daily basis cases. The prediction was performed by the authors (Jia et al. 2020). They used three mathematical models including the Logistic model, Bertalanffy model, and Gompertz model to predict coronavirus cases in three different regions

\footnotetext{
${ }^{1}$ https://www.worldometers.info/coronavirus/
} 
including Wuhan China mainland, and Non-Hubei areas. Logistic regression was found to be the best for the prediction.

Despite the unavailability of a reasonable amount of data, authors made an effort (Zhong et al. 2020) to propose a mathematical model for early prediction of the COVID-19. The historical epidemiological data is used for predictions up till early March. However, according to the current COVID-19 stats, there exist significant variations in predictions. Susceptible-Infected-Removed (SIR) model was used for early prediction of total cases, the unrecovered cases from February to early march (Zhong et al. 2020). The authors have also predicted that the disease will fade out approximately in late June. Based on the results of the prediction, the authors have suggested taking strong anti-epidemic measures to control the spread of disease. SIR model was also used by (Nesteruk 2020) for the prediction of infected, susceptible, and removed persons versus time in mainland China.

Forecasting is another important method that can help the researchers to analyze the seriousness of the situation in the current pandemic. Composite Monte-Carlo, a forecasting method is used by (Fong et al. 2020a) for COVID-19 surveillance. Authors have considered several features from data provided by the Chinese center for disease control and prevention including confirmed cases on the date, cumulative confirmed cases, suspected cases, critically ill, cured cases, deceased cases, recovery rate, and fatality rate from 25 Jan 2020 to 25 Feb 2020. They applied the Composite Monte-Carlo method along with deep learning, rule induction, and with a group of optimized and multisource selection.

Detailed numerical analysis was performed by (Y.-C. Chen et al. 2020) with a proposal and application of a time-dependent SIR model. The problems addressed by the authors are the prediction of the spread of the virus, the peak and end of the pandemic, the effect of asymptotic infections, how to achieve herd immunity and effects of social distancing measures on the spread of disease.

A statistical model to forecast the evolution of coronavirus was studied by (Gamero, Tamayo, and Martinez-Roman 2020). They studied the data provided by the National Health Commission and applied time series analysis, regression, and correlation models on the data. Unlike all other researchers, the authors predicted that the alarming predictions about the pandemic are not going to materialize and the situation will resolve in a period of few days to a few weeks.

An interesting prediction method was applied by (Prasse et al. 2020) who constructed a network of cities in Hubei and their interactions. They considered 16 cities and identified the interaction by traffic patterns between cities. The authors show that network model-based predictions produce better results as compared to the predictions made for the cities individually.

An optimized forecasting model was proposed by (Fong et al. 2020b) based on concepts including the augmentation of existing data, selecting the best forecasting model, and fine-tuning of parameters of individual forecasting. They named it "polynomial neural network with corrective 
feedback" (PNN $+\mathrm{cf})$. results demonstrate that $\mathrm{PNN}+\mathrm{cf}$ was able to produce forecast in given circumstances of the pandemic with acceptable accuracy.Table 2 provides a summary of these methods.

Table 2: Summary of surveillance studies

\begin{tabular}{|c|c|c|}
\hline Study & Method & Findings / Recommendations \\
\hline (Reyad 2020) & $\begin{array}{l}\text { Analysis of COVID-spread in Arab } \\
\text { countries }\end{array}$ & $\begin{array}{l}\text { Report on current statistics of disease, } \\
\text { symptoms, and precautions }\end{array}$ \\
\hline (Brandenburg 2020) & Analysis of disease and fatalities & Rate of deaths is quadratic in nature \\
\hline (Shim et al. 2020) & $\begin{array}{l}\text { Finding an effective reproduction } \\
\text { number and time-dependent } \\
\text { transmission potential }\end{array}$ & $\begin{array}{l}\text { Clustering of infected people according to } \\
\text { source of infection }\end{array}$ \\
\hline $\begin{array}{l}\text { (Zheng, Zi-xia, and } \\
\text { Zu-yao 2020) }\end{array}$ & $\begin{array}{l}\text { Analysis of daily confirmed cases } \\
\text { using he mean, median and } \\
\text { maximum values of the diagnosis } \\
\text { rate }\end{array}$ & $\begin{array}{l}\text { Diagnosis rate of Hubei cities is lower as } \\
\text { compared to cities outside the province. }\end{array}$ \\
\hline $\begin{array}{l}\text { (Elmousalami and } \\
\text { Hassanien 2020) }\end{array}$ & $\begin{array}{l}\text { Time series forecasting (moving } \\
\text { average, weighted moving average, } \\
\text { single exponential smoothing) }\end{array}$ & $\begin{array}{l}\text { Need to apply all the social distancing measure } \\
\text { to stop the spread of disease }\end{array}$ \\
\hline (Jia et al. 2020) & $\begin{array}{l}\text { Logistic model, Bertalanffy model, } \\
\text { and Gompertz model }\end{array}$ & $\begin{array}{l}\text { Among applied models, Logistic model } \\
\text { generates better predictions }\end{array}$ \\
\hline (Zhong et al. 2020) & Susceptible-Infected-Removed & $\begin{array}{l}\text { Social distancing measures shall be applied. The } \\
\text { disease will fade out till late June } 2020\end{array}$ \\
\hline (Nesteruk 2020) & Susceptible-Infected-Removed & $\begin{array}{l}\text { Dependences for victim numbers, infected and } \\
\text { removed persons versus time }\end{array}$ \\
\hline (Fong et al. 2020a) & $\begin{array}{l}\text { Composite Monte Carlo, deep } \\
\text { learning network, fuzzy rule } \\
\text { induction }\end{array}$ & $\begin{array}{l}\text { Decision-makers can get benefit from the } \\
\text { proposed method because it can present the } \\
\text { extreme ranges of future possibilities }\end{array}$ \\
\hline $\begin{array}{l}\text { (Y.-C. Chen et al. } \\
\text { 2020) }\end{array}$ & Time-dependent SIR model & $\begin{array}{l}\text { Predictions about the disease for several } \\
\text { countries and recommendation of social } \\
\text { distancing measures are emphasized }\end{array}$ \\
\hline $\begin{array}{l}\text { (Gamero, Tamayo, } \\
\text { and Martinez-Roman } \\
\text { 2020) }\end{array}$ & Time series analysis and correlation & $\begin{array}{l}\text { Authors concluded that alarming predictions } \\
\text { about the pandemic will not materialize and the } \\
\text { matter will sort out soon. }\end{array}$ \\
\hline (Prasse et al. 2020) & $\begin{array}{l}\text { Network-based modeling along with } \\
\text { SIR method }\end{array}$ & $\begin{array}{l}\text { Network-based modeling approach produces } \\
\text { more accurate results of predictions rather than } \\
\text { modeling the cities independently }\end{array}$ \\
\hline (Fong et al. 2020b) & $\begin{array}{l}\text { Polynomial neural network with } \\
\text { corrective feedback }\end{array}$ & $\begin{array}{l}\text { The proposed method was able to retrieve } \\
\text { results with acceptable accuracy. }\end{array}$ \\
\hline
\end{tabular}

\subsection{COVID 19- Meteorological effect}

In the case of pandemics, past research has shown the role of meteorological parameters on the spread of pandemics and influenzas-based diseases. Some studies have analyzed the effect of weather on the transmission. (B. Chen et al. 2020) studied the effect of air temperature, relative humidity, wind speed, and visibility on the outbreak. They studied the daily data from 430 localities of China, 21 localities of Italy, 21 localities of Japan, and 51 countries of the world ranging from January 20, 2020, to March 11, 2020. It was identified, taking the Chinees cities as training data, that temperature, humidity, and wind speed were predicting the best pandemic situation. 
Another meteorological study was conducted by (Oliveiros et al. 2020). They considered the application of a linear model and a set of four features as independent variables including temperature, humidity, precipitation and wind speed, and the rate of COVID-19 spread as a dependent variable. The doubling time and rate of spread of disease were calculated by the authors and it was observed that doubling time is positively correlated with the temperature and inversely correlated with humidity values. It was concluded by the results that by the arrival of spring and summer, the rate of spread of disease in the northern hemisphere will decrease.

A correlational analysis was conducted to study the relationship between COVID-19 and the weather, particularly for Jakarta which is the capital of Indonesia (Tosepu et al. 2020). It was determined that weather plays an important role to study the prevalence rate of the disease and temperature average is significantly correlated with COVID-19. A relatively more significant examination was carried out by (J. Wang et al. 2020, 19) to study the effect of temperature and humidity on the transmission of COVID-19. The authors hand-collected the data of 4711 cases from 11 provinces of China and after analyzing close contacts, they picked up 105 pairs of virus carriers and infected people. The parameters - temperature and humidity were experimented and pandemic curves were used to study the reproduction rate. It was identified that high temperatures and high humidity will significantly reduce the rate to spread of COVID-19, while cold and dry weather lowers the immunity level of the host. Authors have anticipated that the arrival of summer will reduce the disease. A similar research studies the relationship between meteorological parameters and death rate due to COVID-19 (Ma et al. 2020). The authors studied the temperature variation and humidity and analyzed their relationship with the total number of deaths in Wuhan during a period of Jan 20, 2020, to Feb 29, 2020. It was observed that there is a positive correlation between diurnal temperature range and COVID-19 deaths and a negative correlation between COVID-19 death rate and ambient temperature and absolute humidity.

An interesting study was conducted to check the seasonal effect of COVID19 (Shokouhi et al. 2020, 19) authors studied the climate data from the cities which were highly affected by the pandemic and compared it with the cities which were either not affected or slightly affected. The spread of the outbreak was identified to be compliant with the patterns of a seasonal respiratory virus when studied in restricted latitude, humidity measure, and temperature. Weather models can predict the area that might be at high risk for the transmission of COVID-19.

Table 3 summarizes the work done with meteorological factors.

Table 3: Summary of meteorological effect studies

\begin{tabular}{|l|l|l|}
\hline Study & Method & Findings / Recommendations \\
\hline $\begin{array}{l}\text { (B. Chen et al. } \\
\text { 2020) }\end{array}$ & $\begin{array}{l}\text { Study effect of air temperature, relative } \\
\text { humidity, wind speed, and visibility }\end{array}$ & $\begin{array}{l}\text { Temperature, humidity, and wind speed were found } \\
\text { to be good predictors }\end{array}$ \\
\hline $\begin{array}{l}\text { (Oliveiros et } \\
\text { al. 2020) }\end{array}$ & $\begin{array}{l}\text { Study of spread rate with doubling time } \\
\text { and temperature, humidity, } \\
\text { precipitation, and wind speed }\end{array}$ & $\begin{array}{l}\text { The spread rate will decrease with the arrival of } \\
\text { spring and summer in the northern hemisphere. }\end{array}$ \\
\hline $\begin{array}{l}\text { (Tosepu et al. } \\
\text { 2020) }\end{array}$ & $\begin{array}{l}\text { Spearman Correlational analysis of } \\
\text { weather and COVID-19 }\end{array}$ & $\begin{array}{l}\text { The temperature was found to be significantly } \\
\text { correlated with COVID-19 spread. }\end{array}$ \\
\hline $\begin{array}{l}\text { (J. Wang et al. } \\
\text { 2020) }\end{array}$ & $\begin{array}{l}\text { Linear regression framework to study } \\
\text { reproductive rate }\end{array}$ & $\begin{array}{l}\text { High temperature and humidity reduce the } \\
\text { transmission rate of disease. }\end{array}$ \\
\hline
\end{tabular}




\begin{tabular}{|l|l|l|}
\hline $\begin{array}{l}\text { (Ma et al. } \\
2020)\end{array}$ & $\begin{array}{l}\text { A generalized additive model with a } \\
\text { quasi-Poisson link function }\end{array}$ & $\begin{array}{l}\text { negative correlation among COVID-19 death rate } \\
\text { and ambient temperature and absolute humidity }\end{array}$ \\
\hline $\begin{array}{l}\text { (Shokouhi et } \\
\text { al. 2020, 19) }\end{array}$ & ERA-5 reanalysis & $\begin{array}{l}\text { The spread of COVID-19 is similar to that of a } \\
\text { seasonal virus. Areas at high risk can be predicted } \\
\text { with weather modeling }\end{array}$ \\
\hline
\end{tabular}

\subsection{COVID 19-Social media analytics}

As of March 31, 2020, about 0.8 million cases have been registered over the globe. Consistently, the newly registered cases are rising because of human-to-human transmission is the key source of the virus spread (Munster et al. 2020; Shahid Nadim, Ghosh, and Chattopadhyay 2020). That is why it is very unlikely to estimate the risks and develop remedial policies at the start of or an ongoing outbreak (Heymann 2020). Infectious diseases may have a significant impact on societies in terms of business, traveling, economy, supply chains, manufacturing, and many more. With the rise in social media technology, social networking sites are one of the major sources for emerging opinions' spread among societies. WHO has recognized social media as a platform that can be used to engage and facilitate people, to spread awareness, to effectively communicate, and to detect and respond to rumors (O’Brien, Moore, and McNicholas 2020).

People tend to express fear and anxiety over social media communication platforms, for instance, in terms of economic decline in regard of the COVID-19, social media provides a reliable platform both for businesses and customers to make the right and timely decisions (Ahani and Nilashi 2020). The authors have recommended the use of data analytic tools for the analysis of data that can be obtained from social media sites and its findings shall be used in business decision making.

However, the information on social media platforms such as Twitter may lead to the misrepresentation of the facts (Cinelli et al. 2020). It is because rumors can get amplified in no time because of users of social media networks who keep on spreading the news without checking the credibility of the source. Twitter is one of the social media platforms which may provide rumors and/or questionable information (Cinelli et al. 2020). The high rate of polarization easily leverages the misinformation which is more based on fake news rather than factual information. The authors used an online fact-check organization - MediaBiasFactCheck ${ }^{2}$ regarding the COVID19 news spread patterns. The results illustrate that fact and fake news is more dependent on the audience of a specific platform such as Twitter.

The Twitter-based data of South American countries were analyzed using a text mining approach to study the impact of Coronavirus (Saire 2020). The capital cities of 9 South American countries were selected and Twitter data was extracted for two weeks. The data of the top 100 users were identified. The authors applied steps followed by the Cross-Industry Standard Process for Data Mining process to identify that how the public of these countries is responding towards the pandemic, what are the measures that are found to be effective among people, and what are the issues that are spreading. Authors suggested that infoveillance is an important way to study the trends followed by general people.

\footnotetext{
${ }^{2}$ https://mediabiasfactcheck.com/
} 
A study was conducted to access the fears of the public during the COVID-19 outbreak (Nelson et al. 2020). The authors designed a survey comprising 21 questions and posted it on three social media platforms including Twitter, Facebook, and Nextdoor. It was found that $32 \%$ of the respondents had some illness during last month, $67.3 \%$ of people were highly concerned about coronavirus disease, and $95.7 \%$ of respondents mentioned that they have changed their lifestyle to cope with the outbreak. It was also observed that level of concern variable for the different age groups of respondents.

Social media data was used for the prediction of the coronavirus cases by (Qin et al. 2020). They collected the data from Baidu social media search indexes about cold, cough, flu, fever, chest congestion, and coronavirus. Regarding the aforementioned illnesses, the authors collected data from December 31, 2019, to February 09, 2020, and predicted new cases to be reported from January 20, 2020, to February 9, 2020. Methods including subset selection, forward selection, lasso regression, ridge regression, and elastic net were applied for the prediction task and subset selection was found to be the most optimal method. The authors also concluded that the use of social media search indexes can be used as an effective predictor for the current outbreak.

A summary of the methods that discuss the role of social media networks is given in table 4 .

Table 4: Summary of social media analytics studies

\begin{tabular}{|l|l|l|}
\hline Study & Method & Findings / Recommendations \\
\hline $\begin{array}{l}\text { (Cinelli et } \\
\text { al. 2020). }\end{array}$ & $\begin{array}{l}\text { Natural Language Processing, Clustering, } \\
\text { and Regression }\end{array}$ & $\begin{array}{l}\text { High polarization of social media can cause the } \\
\text { spread of fake news generating panic in the public }\end{array}$ \\
\hline $\begin{array}{l}\text { (Ahani and } \\
\text { Nilashi } \\
2020)\end{array}$ & $\begin{array}{l}\text { Analysis of comments of travelers about } \\
\text { coronavirus outbreak }\end{array}$ & $\begin{array}{l}\text { Social media gives a reliable platform for } \\
\text { business. Data analytic tools shall be used to make } \\
\text { good business decisions }\end{array}$ \\
\hline $\begin{array}{l}\text { (Saire } \\
2020)\end{array}$ & $\begin{array}{l}\text { Cross-Industry Standard Process for Data } \\
\text { Mining }\end{array}$ & $\begin{array}{l}\text { Analysis of tweets related to COVID-19 from top } \\
100 \text { users }\end{array}$ \\
$\begin{array}{l}\text { (Nelson et } \\
\text { al. 2020) }\end{array}$ & $\begin{array}{l}\text { The questionnaire of 21 questions was filled } \\
\text { by social media users. }\end{array}$ & $\begin{array}{l}\text { People have shown their concerns about the } \\
\text { outbreak and 95.7\% of respondents have made } \\
\text { changes in their lifestyle }\end{array}$ \\
\hline $\begin{array}{l}\text { Qin et al. } \\
2020)\end{array}$ & $\begin{array}{l}\text { Use of subset selection, forward selection, } \\
\text { lasso regression, ridge regression, and elastic } \\
\text { net for prediction of new suspected COVID- } \\
\text { 19 cases }\end{array}$ & $\begin{array}{l}\text { Social media search indexes were found to be an } \\
\text { effective early predictor. The subset selection } \\
\text { method was the most optimal method for the task. }\end{array}$ \\
\hline
\end{tabular}

\subsection{COVID 19 - Image processing}

A four-phase image processing system is proposed to detect and assist the pulmonologist to start the treatment from Lung CT images. In the first phase, the possible artifacts from the lung's regions are removed by a threshold filter. In the second phase, images are enhanced. In the third phase, infected regions are obtained by image segmentation and lastly, the Region-of-interest (ROI) is obtained from the binary image (features). The obtained features are further used to identify the severity of the infection level (Rajinikanth et al. 2020).

For the identification of COVID-19 positive cases, a new framework is proposed named as COVID-CAPS. They have proposed to use the Capsule Networks which are capable to deal with dataset having a small number of images. X-ray images are used to detect positive cases and attain 
better results in terms of accuracy, sensitivity, and area under the curve as compared to Convolutional Neural Networks based networks (CNN). COVID-CAPS needs a small number of parameters as compared to CNN's (Afshar et al. 2020).

A deep learning algorithm to diagnose the COVID-19 from the CT image was proposed (S. Wang et al. 2020). Pathogen-confirmed COVID-19 and pneumonia confirmed 453 images were collected. They have selected the random ROI for each positive candidate. Then modified inception migration-learning model was proposed to extract and predict it. Training is being done on 217 images. The results show the effectiveness of using the model based on a deep learning algorithm. In future, clinical, and epidemiological features may be used to enhance the disease diagnosis.

A new real-time COVID-19 detection imagining system was proposed and named as joint classification and segmentation (JCS) system (Wu et al. 2020). Training is accomplished by building a large-scale image data set with a total of 144,167 CT images from 350, and 400 uninfected and infected patients respectively. To improve the diagnosis, 3855 images from the 200 patients are fine-grained pixel-level annotated with the locations, lesion count, and infected areas. They have proposed to used encoder-decoder based segmentation. The classification phase is divided into two phases, in the first phase, Res2Net network is used and in second phase activation mapping is used to increase the transparency.

An automatic and efficient early-stage framework based on a deep learning model is proposed named COVIDX-Net (Hemdan, Shouman, and Karar 2020). COVIDX-Net contains seven deep convolutional neural network models. Each of these can perform well on x-ray image normalized intensities to correctly identify the suspected patient as positive or negative. Training is done on $80 \%$ of the images and remaining images are used as testing. They concluded that low cost and efficient result can be achieved by using the X-ray as compared to others, like CT. In the future, clinical studies may be used to enhance the performance of the system performance.

(Narin, Kaya, and Pamuk 2020) proposed to use three different types of convolutional neural networks to detect the positive samples of COVID-19 from the X-ray images. There is no need for any feature extraction method separately because it's an end-to-end learning method. They have analyzed all three models by utilizing the 5 -fold cross-validation. Due to a limited number of images, in future deep transfer learning models can be used.

A new image segmentation method for CT images based on the deep learning algorithm is proposed to identify the infected regions named as residual attention U-Net model (X. Chen, Yao, and Zhang 2020). Salient feature representation is learned by applying the Aggregated Residual Transformations. Also, soft attention mechanism is used to improve the capacity of the proposed model, and to differentiate the variability of COVID-19 symptoms. In the future, a hybrid attention model can be used to generate a better semantic explanation.

A patch-based convolutional neural network technique is proposed to overcome the problem of small data size for x-ray images (Oh, Park, and Ye 2020). A patch-based approach needs a smaller number of parameters to train the model as compared to a convolutional neural network. The proposed approach has two phases in first phase images are segmented into lung contours. In the 
second phase, lung contours are divided into random patches and given the input to the classifier. The summary of the methods that perform image processing is shown in table 5 .

Table 5: Summary of image processing studies

\begin{tabular}{|l|l|l|}
\hline Study & Method & Findings / Recommendations \\
\hline $\begin{array}{l}\text { (Rajinikanth et al. } \\
\text { (Afshar et al. 2020) }\end{array}$ & $\begin{array}{l}\text { Four phase imaging } \\
\text { system }\end{array}$ & COVID-CAPS. \\
\hline $\begin{array}{l}\text { (S. Wang et al. } \\
\text { I020) }\end{array}$ & $\begin{array}{l}\text { A deep learning } \\
\text { algorithm }\end{array}$ & Performs better as compared to CNN's based networks. \\
\hline $\begin{array}{l}\text { (Wu et al. 2020) } \\
\text { Soint Classification and } \\
\text { System }\end{array}$ & $\begin{array}{l}\text { The classification model is used to identify the suspected } \\
\text { patient as positive or not, where the segmentation provides } \\
\text { the visual perception of the patient. }\end{array}$ \\
\hline $\begin{array}{l}\text { Shemdan, } \\
\text { Karar 2020) }\end{array}$ & COVIDX-Net \\
\hline $\begin{array}{l}\text { Narin, Kaya, and } \\
\text { Pamuk 2020) }\end{array}$ & $\begin{array}{l}\text { Analysis of three } \\
\text { different DNN }\end{array}$ & $\begin{array}{l}\text { Low-cost x-ray images can be affectedly used for the } \\
\text { diagnosis of COVID-19. }\end{array}$ \\
\hline $\begin{array}{l}\text { (X. Chen, Yao, and } \\
\text { Zhang 2020) }\end{array}$ & $\begin{array}{l}\text { Residual attention U-Net } \\
\text { model }\end{array}$ & $\begin{array}{l}\text { Salient image features are learned with Aggregated Residual } \\
\text { Transformations with improved U-Net model. }\end{array}$ \\
\hline $\begin{array}{l}\text { (Oh, Park, and Ye } \\
\text { 2020) }\end{array}$ & $\begin{array}{l}\text { Patch-based } \\
\text { convolutional neural } \\
\text { network }\end{array}$ & $\begin{array}{l}\text { Reduced the complexity of the model by considering the } \\
\text { patches instead of the complete image. }\end{array}$ \\
\hline
\end{tabular}

\subsection{COVID 19 - Economy and business}

The coronavirus outbreak has serious implications for the world's economy and businesses. The social distancing measures and periods of isolation have their cost in terms of loss of work time and are eventually contributing to economic loss. Not only that COVID-19 has been declared as a public health emergency by WHO, it is also suspected to surpass the global financial crisis of 2008-09 (Loayza and Pennings 2020).

A major drawback of the COVID-19 is a noteworthy decline in the world economy (Yilmazkuday 2020). The authors investigated the effects of COVID-19 on the global economy using the Baltic Exchange Dry Index (BDI) and Structural Vector Auto Regressive (S-VAR) model. The results depict that a rapid increase in daily deaths decreased the cumulative reduction in BDI by $10 \%$. The crude oil prices (COP) are not affected significantly by the COVID-19. Likewise, using the data for the period Jan 21, 2020, to Mar 13, 2020, the authors made another effort (Albulescu 2020) to study the effect of the COVID-19 and COP on the United States economic policy. Using the Auto Regressive Distributed Lag (ARDL) model, the results show that the variables such as the total number of cases reported, the death rate does not have a substantial effect on the US economy, particularly.

Macroeconomic outcomes with the evolvement of the COVID-19 outbreak were studied in seven different scenarios of attack rate, fatality rate, and mortality rate (McKibbin and Fernando 2020). The study of these scenarios presents that even if the outbreak is contained, it will still cost a high 
impact on the global economy. The scale of these costs can be reduced by investment in the health sector, especially in countries where health facilities are not significantly developed.

The Gross Domestic Product (GDP) is a seriously affected variable by the COVID-19 (Fernandes 2020). The authors analyzed the relationship between the GDP growth rate and the effects of the COVID-19 on different countries. The results demonstrate that the current global lockdowns can account for $2-2.5 \%$ of the global GDP growth. The economics which is operating on serviceoriented based architecture will have a negative effect by turning several industrial jobs at risk. Also, the tourism-rich states will be extremely hurt by the COVID-19 up to more than $15 \%$ of GDP.

In the current scenario of the pandemic, only the most authentic information shall be disclosed to control the economic loss. Because inappropriate information can be the cause of public panic and discomfort, and also, underestimation can cause of lack of awareness in public. A suitable balance is required to keep people aware and keep the economic loss to a minimum and fighting the disease. (Gong et al. 2020). The authors studied SARS, H1N1, and Ebola along with the COVID-19 and emphasized that it is not the disease itself that caused the immense economic decline. However, the time consumed in caring for the patient, the fear, and the panic spread among the society due to disinformation is the key reason for this decline.

Stock returns of 10 countries were analyzed in the first 10 weeks of 2020 (Nguyen 2020). Among the 11 sectors that were studied, Communication Services, Consumer Staples, Health Care, Information Technology, and Utilities were found to be going comparatively better than remaining sectors in all countries excluding Japan, the United States of America, and Italy. In countries including Canada, Italy, the United Kingdom, and the United States of America, the energy sector was found to be facing abnormal negative returns. Overall, Japan and the United States of America have more number of sectors that show abnormal or negative returns.

An analysis of socio-economic factors during the pandemic was conducted by (Evans 2020). The author mentions that in the current scenario the economic conditions can disturb health, trade, travel, agriculture, industry, and various types of markets. The author studied the literature related to previous pandemics and suggested some policies for the current pandemic. It includes active management policies, determining harmful factors for health, shifts in investment, and the launch of World Technical Council specifically for coronavirus.

The health experts have used several SIR models to estimate the impact of coronavirus and to make recommendations for the mitigation of the disease. (Atkeson 2020) made an effort for economists to help them understand the quantitative implications of these SIR models. Therefore, they can be a part of policy decision-making regarding the health of people and the effect of social distancing measures on the economy. It is challenging to estimate the economic cost and a cumulative loss of work time due to the imposition of social distancing measures over 12 to 18 months. The author explained that at the peak of the progression of the disease, about 10 to $20 \%$ of the US population can be affected, causing a huge loss of workforce and at the same time it will 
cost massive investments in health care. Likewise, authors (Toda 2020). used SIR model and predicted that $26 \%$ of the global population can get affected at the peak of progression of the disease which will seriously overwhelm the healthcare facilities. With the application of optimal mitigation policies, the number can be reduced to $6.2 \%$. A similar study was conducted by (Alvarez, Argente, and Lippi 2020) to understand the optimal policy for lockdown and its economic costs. They applied SIR model and identified that features including the number of infected cases and the rate of fatalities are involved in determining the duration and intensity of optimal lockdown policy. It was also found by experimentation that the absence of testing can also significantly increase the economic cost of lockdown.

The summary of the methods that address the economy or business problems during the pandemic are shown in table 6.

Table 6: Summary of business and economics studies

\begin{tabular}{|c|c|c|}
\hline Study & Method & Findings / Recommendations \\
\hline $\begin{array}{l}\text { (Yilmazkuday } \\
\text { 2020) }\end{array}$ & $\begin{array}{l}\text { Structural vector autoregression. } \\
\text { Relationship of daily deaths } \\
\text { with changes in BDI and crude } \\
\text { oil prices }\end{array}$ & $\begin{array}{l}\text { A rapid increase in daily deaths decreased the } \\
\text { cumulative reduction in BDI by } 10 \% \text { and no effect on } \\
\text { BDI }\end{array}$ \\
\hline (Albulescu 2020) & $\begin{array}{l}\text { Autoregressive Distributed Lag } \\
\text { model. Effect of deaths on } \\
\text { United States economic policy } \\
\text { uncertainty }\end{array}$ & $\begin{array}{l}\text { Features like the number of cases reported the death rate } \\
\text { does not have a substantial effect on the US economy }\end{array}$ \\
\hline (Fernandes 2020) & $\begin{array}{l}\text { Analysis of the effect of } \\
\text { outbreak on the world's } \\
\text { economy }\end{array}$ & $\begin{array}{l}\text { Lockdowns over the globe can account } 2-2.5 \% \text { of the } \\
\text { global GDP growth }\end{array}$ \\
\hline (Gong et al. 2020) & $\begin{array}{l}\text { The economic impact of } \\
\text { pandemics }\end{array}$ & $\begin{array}{l}\text { Fear and panic due to disinformation cause loss to the } \\
\text { economy }\end{array}$ \\
\hline (Nguyen 2020) & $\begin{array}{l}\text { Analyzing abnormal returns in } \\
11 \text { different stocks of } 10 \\
\text { different countries }\end{array}$ & $\begin{array}{l}\text { Investors across sectors and countries respond } \\
\text { differently during the outbreak. Markets of Asian } \\
\text { countries show the early effect as compared to European } \\
\text { markets }\end{array}$ \\
\hline (Evans 2020) & Policy solutions & $\begin{array}{l}\text { Policy solutions from previous pandemics and the } \\
\text { literature }\end{array}$ \\
\hline (Atkeson 2020) & SIR model & $\begin{array}{l}\text { Significant economic tradeoff in both conditions, (with } \\
\text { and without social distancing measures). Serious social } \\
\text { distancing measures are required for a year or } 18 \text { months } \\
\text { to avoid public health consequences }\end{array}$ \\
\hline (Toda 2020) & SIR model & $\begin{array}{l}\text { With optimal mitigation policies, the rate of infected } \\
\text { people at suspected peak can be significantly reduced }\end{array}$ \\
\hline $\begin{array}{l}\text { (Alvarez, } \\
\text { Argente, and } \\
\text { Lippi 2020) }\end{array}$ & SIR model & $\begin{array}{l}\text { The economic cost of the lockdown is related to the } \\
\text { reported cases and fatalities }\end{array}$ \\
\hline $\begin{array}{l}\text { (McKibbin and } \\
\text { Fernando 2020) }\end{array}$ & $\begin{array}{l}\text { Global hybrid DSGE/CGE } \\
\text { general equilibrium model }\end{array}$ & $\begin{array}{l}\text { Greater investment in the public health sector is required } \\
\text { to reduce the economic loss }\end{array}$ \\
\hline
\end{tabular}




\section{Datasets}

In order to understand the COVID-19 from a variety of aspects, five different categories of studies are covered that involve the current pandemic named Coronavirus. For all these categories, different types of dataset were under consideration. However, some common features presented in most of the datasets are confirmed cases, the confirmed deaths, the active cases, and the recovered cases. In this section, we give summaries of the dataset used by different categories in tabular form. Table 7 , table 8 , table 9 , table 10 and table 11 summarizes the datasets used by surveillance, meteorological effect, social media analytics, image processing, and business and economy methods, respectively.

Table 7: Surveillance datasets

\begin{tabular}{|c|c|c|c|}
\hline Study & Dataset & Features & Duration \\
\hline (Reyad 2020) & Data of Arab Countries & Total cases and total deaths & $\begin{array}{l}\text { Not } \\
\text { mentioned }\end{array}$ \\
\hline $\begin{array}{l}\text { (Brandenburg } \\
\text { 2020) }\end{array}$ & $\begin{array}{l}\text { World Health Organization, } \\
\text { DEVEX, Worldometers }\end{array}$ & $\begin{array}{l}\text { Numbers of fatalities, number of } \\
\text { infections, a fraction of fatalities per } \\
\text { infection }\end{array}$ & $\begin{array}{l}\text { Jan } 03, \\
2020, \text { to Feb } \\
09,2020\end{array}$ \\
\hline (Shim et al. 2020) & $\begin{array}{l}\text { Korea Centers for Disease } \\
\text { Control and Prevention }\end{array}$ & $\begin{array}{l}\text { Reporting dates of confirmed cases, date } \\
\text { of symptom onset of the first } 28 \text { cases, } \\
\text { type of case }\end{array}$ & $\begin{array}{l}\text { Jan } 20, \\
2020, \text { to Feb } \\
26,2020\end{array}$ \\
\hline 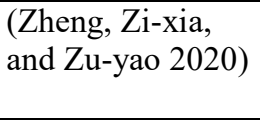 & Wuhan migration data & $\begin{array}{l}\text { Number of infected people, the diagnosis } \\
\text { rate }\end{array}$ & $\begin{array}{l}\text { Jan } 29, \\
2020, \text { to Feb } \\
09,2020\end{array}$ \\
\hline $\begin{array}{l}\text { (Elmousalami and } \\
\text { Hassanien 2020) }\end{array}$ & $\begin{array}{l}\text { Data by national health } \\
\text { commission of China and Jhon } \\
\text { Hopkin university }\end{array}$ & $\begin{array}{l}\text { Date, Province, Country, confirmed cases } \\
\text { till date, deaths till date, recovered cases } \\
\text { till date. }\end{array}$ & $\begin{array}{l}\text { Jan 23, } \\
\text { 2020, to Mar } \\
09,2020\end{array}$ \\
\hline (Jia et al. 2020) & $\begin{array}{l}\text { Data of } 31 \text { provinces and } \\
\text { Xinjiang Production and } \\
\text { Construction Corps. }\end{array}$ & $\begin{array}{l}\text { Date, Number of confirmed cases, new } \\
\text { cases on the date, number of deaths. }\end{array}$ & $\begin{array}{l}\text { Jan } 15, \\
\text { 2020, to Apr } \\
04,2020\end{array}$ \\
\hline $\begin{array}{l}\text { (Zhong et al. } \\
\text { 2020) }\end{array}$ & $\begin{array}{l}\text { Wuhan Municipal Health } \\
\text { Commission, Health } \\
\text { Commission of Hubei } \\
\text { Province, National Health } \\
\text { Commission of the People's } \\
\text { Republic of China } \\
\end{array}$ & $\begin{array}{l}\text { Cumulative confirmed cases, deaths, } \\
\text { suspected cases, recovered cases, } \\
\text { infection rate, removal rate. }\end{array}$ & $\begin{array}{l}\text { Dec } 31, \\
2019, \text { to Jan } \\
19,2020\end{array}$ \\
\hline (Nesteruk 2020) & $\begin{array}{l}\text { China National Health } \\
\text { Commission }\end{array}$ & $\begin{array}{l}\text { Time, number of cases, confirmed cases, } \\
\text { recovered cases }\end{array}$ & $\begin{array}{l}\text { Jan } 16, \\
2020, \text { to Feb } \\
09,2020\end{array}$ \\
\hline $\begin{array}{l}\text { (Fong et al. } \\
\text { 2020a) }\end{array}$ & $\begin{array}{l}\text { Chinese Center for Disease } \\
\text { Control and Prevention and } \\
\text { time-series data }\end{array}$ & $\begin{array}{l}\text { cumulative confirmed cases, current } \\
\text { number of confirmed cases, current } \\
\text { number of suspected cases, current } \\
\text { number of critically ill, cumulative } \\
\text { number of cured cases, cumulative } \\
\text { number of deceased cases, recovery rate } \\
\text { and fatality rate }\end{array}$ & $\begin{array}{l}\text { Jan } 25, \\
2020, \text { to Feb } \\
25,2020\end{array}$ \\
\hline $\begin{array}{l}\text { (Y.-C. Chen et al. } \\
\text { 2020) }\end{array}$ & $\begin{array}{l}\text { National Health Commission of } \\
\text { China }\end{array}$ & $\begin{array}{l}\text { Number of confirmed cases, the number } \\
\text { of recovered persons, and the number of } \\
\text { deaths }\end{array}$ & $\begin{array}{l}\text { Jan 15, } \\
\text { 2020, to Mar } \\
02,2020\end{array}$ \\
\hline $\begin{array}{l}\text { (Gamero, } \\
\text { Tamayo, and } \\
\text { Martinez-Roman } \\
\text { 2020). }\end{array}$ & $\begin{array}{l}\text { China's National Health } \\
\text { Commission }\end{array}$ & Number of confirmed cases & $\begin{array}{l}\text { Not } \\
\text { mentioned }\end{array}$ \\
\hline
\end{tabular}




\begin{tabular}{|l|l|l|l|}
\hline $\begin{array}{l}\text { (Prasse et al. } \\
2020)\end{array}$ & $\begin{array}{l}\text { Time series data on 16 Hubei } \\
\text { cities }\end{array}$ & Number of reported infections & $\begin{array}{l}\text { Jan 21, } \\
2020, \text { to Feb } \\
08,2020\end{array}$ \\
\hline $\begin{array}{l}\text { (Fong et al. } \\
2020 \mathrm{~b})\end{array}$ & $\begin{array}{l}\text { Archive of Chinese health } \\
\text { authorities }\end{array}$ & $\begin{array}{l}\text { Confirmed cases, cured cases, suspected } \\
\text { cases, critical case, deaths }\end{array}$ & $\begin{array}{l}\text { Jan } 21, \\
2020, \text { to Feb } \\
03,2020\end{array}$ \\
\hline
\end{tabular}

Table 8: Meteorological effect datasets

\begin{tabular}{|c|c|c|c|}
\hline Study & Dataset & Features & Duration \\
\hline (B. Chen et al. 2020) & Daily data of 53 countries & $\begin{array}{l}\text { Air temperature, relative } \\
\text { humidity, wind speed, and } \\
\text { visibility }\end{array}$ & $\begin{array}{l}\text { Jan 20, 2020, to Mar 11, } \\
2020\end{array}$ \\
\hline (Oliveiros et al. 2020) & 31 provinces of China & $\begin{array}{l}\text { Confirmed cases, } \\
\text { temperature, humidity, } \\
\text { precipitation, and wind } \\
\text { speed }\end{array}$ & $\begin{array}{l}\text { Jan 23, 2020, to Mar 01, } \\
2020\end{array}$ \\
\hline (Tosepu et al. 2020) & $\begin{array}{l}\text { Ministry of Health of the } \\
\text { Republic of Indonesia and } \\
\text { weather from the } \\
\text { Meteorological } \\
\text { Department of the } \\
\text { Republic of Indonesia }\end{array}$ & $\begin{array}{l}\text { Minimum, maximum and } \\
\text { average temperature, } \\
\text { humidity, amount of } \\
\text { Rainfall }\end{array}$ & $\begin{array}{l}\text { January - March 29, } \\
2020\end{array}$ \\
\hline (J. Wang et al. 2020) & $\begin{array}{l}105 \text { hand-collected pairs } \\
\text { of the virus carrier and the } \\
\text { infected from } 100 \text { cities } \\
\text { of China }\end{array}$ & $\begin{array}{l}\text { Temperature and } \\
\text { humidity. }\end{array}$ & January 21 to 23,2020 \\
\hline (Ma et al. 2020) & $\begin{array}{l}\text { Data of Wuhan from the } \\
\text { Health Commission of } \\
\text { Hubei Province }\end{array}$ & $\begin{array}{l}\text { Death number, air } \\
\text { pollutant data, } \\
\text { temperature, humidity }\end{array}$ & $\begin{array}{l}\text { Jan 20, 2020, to Feb 29, } \\
2020\end{array}$ \\
\hline (Shokouhi et al. 2020, 19) & $\begin{array}{l}\text { Monthly climate data } \\
\text { from cities across the } \\
\text { globe }\end{array}$ & $\begin{array}{l}\text { Average temperature, } \\
\text { relative humidity, specific } \\
\text { humidity, and absolute } \\
\text { humidity }\end{array}$ & Nov 2019 to Feb 2020 \\
\hline
\end{tabular}

Table 9: Social media analytics datasets

\begin{tabular}{|l|l|l|l|}
\hline Study & Dataset & Features & Duration \\
\hline (Cinelli et al. 2020). & $\begin{array}{l}\text { 45 days data from } \\
\text { Twitter, Instagram, } \\
\text { YouTube, Reddit and Gab }\end{array}$ & $\begin{array}{l}\text { Posts, comments, users } \\
\text { time }\end{array}$ & $\begin{array}{l}\text { Jan 01, 2020, to Feb 14, } \\
2020\end{array}$ \\
\hline (Ahani and Nilashi 2020) & $\begin{array}{l}\text { Data of travelers from } \\
\text { TripAdvisor.com }\end{array}$ & $\begin{array}{l}\text { Global survey filled by } \\
1170 \text { travelers }\end{array}$ & $\begin{array}{l}\text { Feb 26, 2020 to Feb 27, } \\
2020\end{array}$ \\
\hline (Saire 2020) & $\begin{array}{l}\text { Twitter data from capital } \\
\text { cities of 9 countries of } \\
\text { South American }\end{array}$ & $\begin{array}{l}\text { User posts, top 100 users } \\
\text { of each country }\end{array}$ & $\begin{array}{l}\text { Mar 08- 020 to Mar 21, } \\
2020\end{array}$ \\
\hline (Nelson et al. 2020) & $\begin{array}{l}\text { Survey collected form } \\
\text { participants of social } \\
\text { media including Twitter, } \\
\text { Facebook, and Nextdoor }\end{array}$ & $\begin{array}{l}\text { 21 questions about topics } \\
\text { like recent illness, } \\
\text { lifestyle, modifications in } \\
\text { lifestyle }\end{array}$ & $\begin{array}{l}\text { Mar 14, 2020, to Mar 16, } \\
2020\end{array}$ \\
\hline (Qin et al. 2020) & $\begin{array}{l}\text { Baidu Search Index in } \\
\text { Social Media }\end{array}$ & $\begin{array}{l}\text { Cases reported about cold, } \\
\text { cough, flu, fever, chest } \\
\text { congestion } \\
\text { coronavirus }\end{array}$ & $\begin{array}{l}\text { Dec 31, 2019, to Feb 09, } \\
\text { 2020 }\end{array}$ \\
\hline
\end{tabular}


Table 10: Image processing datasets

\begin{tabular}{|c|c|}
\hline Study & Dataset \\
\hline (Rajinikanth et al. 2020). & $\begin{array}{l}\text { Radiopedia database clinical-grade chest X-ray, } 90 \text { 2D slices of coronal-view and } 20 \\
\text { 2D slices of axial-view }\end{array}$ \\
\hline (Afshar et al. 2020) & $\begin{array}{l}112120 \text { Chest X-ray images for } 14 \text { thorax } \\
\text { abnormalities }\end{array}$ \\
\hline (S. Wang et al. 2020a) & $\begin{array}{l}\text { CT images from } 99 \text { patients with } 55 \text { cases of typical viral pneumonia and } 44 \text { other } \\
\text { cases }\end{array}$ \\
\hline (Wu et al. 2020) & $\begin{array}{l}\text { 144,167 CT images of } 400 \text { COVID-19 patients } \\
\text { and } 350 \text { uninfected cases }\end{array}$ \\
\hline $\begin{array}{l}\text { (Hemdan, Shouman, and } \\
\text { Karar 2020) }\end{array}$ & 50 Chest X-ray images with 25 confirmed positive COVID-19 cases. \\
\hline $\begin{array}{l}\text { (Narin, Kaya, and Pamuk } \\
\text { 2020) }\end{array}$ & Chest X-ray images of 50 normal and 50 COVID-19 patients \\
\hline $\begin{array}{l}\text { (X. Chen, Yao, and } \\
\text { Zhang 2020) }\end{array}$ & 110 axial CT images collected from 60 patients \\
\hline (Oh, Park, and Ye 2020) & $\begin{array}{l}\text { Segmentation network dataset with } 247 \text { chest posteroanterior radiographs and } \\
\text { Classification dataset with } 502 \text { images curated from multile sources }\end{array}$ \\
\hline
\end{tabular}

Table 11: Economy and business datasets

\begin{tabular}{|c|c|c|c|}
\hline Study & Dataset & Features & Duration \\
\hline (Yilmazkuday 2020) & $\begin{array}{l}\text { Daily statistics from U.S. } \\
\text { Energy Information } \\
\text { Administration and Baltic } \\
\text { Exchange Dry Index } \\
\text { fromweb page of Trading } \\
\text { Economics }\end{array}$ & $\begin{array}{l}\text { Daily statistics of the } \\
\text { disease, Baltic Exchange } \\
\text { Dry Index and crude oil } \\
\text { prices }\end{array}$ & $\begin{array}{l}\text { Dec 31, 2019, to Mar 27, } \\
2020\end{array}$ \\
\hline (Albulescu 2020) & $\begin{array}{l}\text { Daily statistics from } \\
\text { WHO situation reports } \\
\text { and oil prices from US } \\
\text { Energy Information } \\
\text { Administration }\end{array}$ & $\begin{array}{l}\text { Daily statistic of disease } \\
\text { including deaths }\end{array}$ & $\begin{array}{l}\text { Jan } 21,2020, \text { to Mar } 13, \\
2020\end{array}$ \\
\hline (Fernandes 2020) & $\begin{array}{l}\text { World trade organization, } \\
\text { international monetary } \\
\text { fund }\end{array}$ & $\begin{array}{l}\text { China's imports and } \\
\text { export and its GDP }\end{array}$ & $\begin{array}{l}\text { The paper mentions "first } \\
\text { months of } 2020 \text { " }\end{array}$ \\
\hline (Gong et al. 2020) & $\begin{array}{l}\text { Data of SARS, H1N1, } \\
\text { Ebola, and COVID-19 }\end{array}$ & $\begin{array}{l}\text { Features at micro-, sector- } \\
\text {, and macro-level }\end{array}$ & Not mentioned \\
\hline (Nguyen 2020). & $\begin{array}{l}\text { Data of publicly traded } \\
\text { companies for Canada, } \\
\text { China, France, Germany, } \\
\text { Italy, Japan, South Korea, } \\
\text { Spain, the United } \\
\text { Kingdom, and the United } \\
\text { States }\end{array}$ & $\begin{array}{l}24,926 \text { publicly listed } \\
\text { companies from } 10 \\
\text { countries }\end{array}$ & $\begin{array}{l}\text { Jan 03, 2018, to Mar 11, } \\
2020\end{array}$ \\
\hline (Evans 2020) & $\begin{array}{l}\text { European Centre for } \\
\text { Disease Prevention and } \\
\text { Control }\end{array}$ & $\begin{array}{l}\text { Confirmed cases and } \\
\text { deaths }\end{array}$ & $\begin{array}{l}\text { Jan } 01,2020, \text { to Mar 06, } \\
2020\end{array}$ \\
\hline (Atkeson 2020) & $\begin{array}{l}\text { Various sources from } \\
\text { China, US, Europe }\end{array}$ & $\begin{array}{l}\text { Cummulative cases, } \\
\text { active cases }\end{array}$ & $\begin{array}{l}\text { Jan } 24,2020, \text { to Feb 08, } \\
2020\end{array}$ \\
\hline
\end{tabular}




\begin{tabular}{|l|l|l|l|}
\hline (Toda 2020) & $\begin{array}{l}\text { Center for Systems } \\
\text { Science and Engineering } \\
\text { at Johns Hopkins } \\
\text { University }\end{array}$ & $\begin{array}{l}\text { Confirmed cases and } \\
\text { deaths }\end{array}$ & $\begin{array}{l}\text { Mar 13, 2020, to Mar 26, } \\
2020\end{array}$ \\
\hline $\begin{array}{l}\text { (Alvarez, Argente, and } \\
\text { Lippi 2020) }\end{array}$ & $\begin{array}{l}\text { Center for Systems } \\
\text { Science and Engineering } \\
\text { at Johns Hopkins } \\
\text { University }\end{array}$ & $\begin{array}{l}\text { Confirmed cases, } \\
\text { recovered cases and } \\
\text { deaths }\end{array}$ & $\begin{array}{l}\text { Data of the first 25 days } \\
\text { of all countries that cross } \\
\text { the threshold of } 100 \\
\text { active cases }\end{array}$ \\
\hline $\begin{array}{l}\text { (McKibbin and Fernando } \\
\text { 2020) }\end{array}$ & $\begin{array}{l}\text { Publicly available } \\
\text { epidemiological data }\end{array}$ & $\begin{array}{l}\text { Attack, fatality and } \\
\text { mortality rates }\end{array}$ & Not mentioned \\
\hline
\end{tabular}

\section{Future Directions and Challenges}

Towards better understanding of the disease spread patterns, some important future directions andresearch challenges are summarized below.

\subsection{Information collection and use of advanced analytical/mathematical models}

There is a foremost need for timely collection of information about the pandemic for better surveillance. The prevention and control are highly dependent on the timely policymaking to control the spread of the virus (Gong et al. 2020). Once we have reliable information about the disease, we need wide-ranging science-based methods to process pandemic information (Gong et al. 2020). The researchers have suggested the use of advanced big data analytic techniques to analyze the data available on social media web sites. It can help for several business and customers for decision-making tasks in such a curial time of pandemic (Ahani and Nilashi 2020). The analysis of data on day to day basis is required to get more precise results from mathematical models and prediction tasks (Nesteruk 2020; Gamero, Tamayo, and Martinez-Roman 2020; B. Chen et al. 2020). We suggest that the prediction methods shall be trained with most up to date data to keep track of daily changes and gaining up to date prediction results. An exhaustive research study is required to relate the technical forecast with the nontechnical decision-making process in such a way that both can complement each other for better decision making (Fong et al. 2020a; 2020b). SIR model has been extensively used in the literature for the forecasting of disease. There is a need to further extend the deterministic SIR model by using stochastic models like the nonhomogeneous Markov chain. This can enhance the precision of the prediction results (Y.-C. Chen et al. 2020; Prasse et al. 2020).

\subsection{Effect of meteorological features}

Meteorological features including humidity, temperature also play a role in the spread of the disease. Individual health factors such as hand washing habits, personal hygiene, and use of hand sanitizers may be the other related factors of COVID-19 that are necessary to be explored (Tosepu et al. 2020). Although the findings of meteorological variable-based studies suggest that spread of the pandemic will significantly reduce with the arrival of summer.However, there is still a strong need of implementing the social distancing measures (J. Wang et al. 2020, 19).

\subsection{Requirement of the advanced social media framework}

The information can be effectively shared with the help of social media on one hand, while on the other hand, there is a strong need to identify the rumor-based information. A conceptual framework in the form of a social network can be used to study the collective behavior of the COVID-19 
pandemic (Chan et al. 2020). Also its is very important to regularly analyse how people are racting / showing emotions to news or press confercences done by governments by investigating tweet peaks through words clouds.

\subsection{Requirement of a large number of images for better training of image processing models}

COVID-19 is new and has a small number of available image repositories. In the future, more images may be added to repositories to learn the deep neural networks. Due to the limited number of images, deep transfer learning models can be used (Narin, Kaya, and Pamuk 2020). Clinical, and epidemiological features may be used to enhance the disease diagnosis (S. Wang et al. 2020; Hemdan, Shouman, and Karar 2020). A hybrid attention model can be used to generate a better semantic explanation (X. Chen, Yao, and Zhang 2020).

\subsection{Requirement of cooperation of all stakeholders for effective implementation of business policies}

There is a need for rapid and authoritative dissemination of authentic pandemic information. The timely dissemination of authentic information about pandemics is an important component of effective prevention and control (Gong et al. 2020). Regarding the socio-economic impact of COVID-19, it is very important to effectively implement the policies by the governmental bodies. All the stake-holders of the whole community including health departments, media, nongovernment bodies, communities, and the public, shall ensure their maximum cooperation to implement the policy solutions (Evans 2020). The COVID-19 outbreak not only impacts the socioeconomic factors but it is also affecting the global economy and GDP. Studies have been conducted to evaluate the effect of the pandemic on businesses, and similar studies are required to estimate the effect on airlines, machinery industries, and sub-division associated with the industrial sectors (Nguyen 2020). Macroeconomic policies are required to implement in developing countries to support public services and economics (Loayza and Pennings 2020).

\section{Conclusion}

Covid-19 pandemic has suddenly brought the whole world on their knees. Science and computing world are trying their level best to come up with some solutions to deal with it and study its impact on future. From our survey, it can be concluded that five categories of research domains are being investigated in computing; surveillance, meter-logical, social media, image processing, and business and economy. Researchers are trying to come up with intuitive analysis and methods but still there are many things needed to be clear in these areas. The sudden and unique nature of COVID-19 have opened a number of research issues in different domains like the following:Information collection and use of advanced analytical/mathematical models

- Investigation of meteorological impact on human health

- Requirement of advanced social media framework

- Need of large image processing datasets with diversity for better training of image processing models and patterns recognition and

- Impact analysis of COVID-19 on economy, which may bring new economic policies to smartly deal with this type of pandemics in future 
In this beginning of new area of research, we do believe that the categorization of methods, datasets and future directions presented will be useful for the researchers for now, and in the near future as well.

\section{References}

Afshar, Parnian, Shahin Heidarian, Farnoosh Naderkhani, Anastasia Oikonomou, Konstantinos N. Plataniotis, and Arash Mohammadi. 2020. "COVID-CAPS: A Capsule Network-Based Framework for Identification of COVID-19 Cases from X-Ray Images." ArXiv Preprint ArXiv:2004.02696.

Ahani, Ali, and Mehrbakhsh Nilashi. 2020. "Coronavirus Outbreak and Its Impacts on Global Economy: The Role of Social Network Sites." Journal of Soft Computing and Decision Support Systems 7 (2): 1922.

Albulescu, Claudiu. 2020. ArXiv Preprint ArXiv:2003.07591.

Alvarez, Fernando E., David Argente, and Francesco Lippi. 2020. "A Simple Planning Problem for Covid-19 Lockdown." National Bureau of Economic Research.

Atkeson, Andrew. 2020. "What Will Be the Economic Impact of COVID-19 in the US? Rough Estimates of Disease Scenarios." National Bureau of Economic Research.

Brandenburg, Axel. 2020. "Quadratic Growth during the 2019 Novel Coronavirus Epidemic." ArXiv Preprint ArXiv:2002.03638.

Chan, A. K. M., C. P. Nickson, J. W. Rudolph, and A. Lee GM Joynt. 2020. "Social Media for Rapid Knowledge Dissemination: Early Experience from the COVID-19 Pandemic."

Chen, Biqing, Hao Liang, Xiaomin Yuan, Yingying Hu, Miao Xu, Yating Zhao, Binfen Zhang, Fang Tian, and Xuejun Zhu. 2020. "Roles of Meteorological Conditions in COVID-19 Transmission on a Worldwide Scale." MedRxiv.

Chen, Xiaocong, Lina Yao, and Yu Zhang. 2020. "Residual Attention U-Net for Automated Multi-Class Segmentation of COVID-19 Chest CT Images." ArXiv Preprint ArXiv:2004.05645.

Chen, Yi-Cheng, Ping-En Lu, Cheng-Shang Chang, and Tzu-Hsuan Liu. 2020. "A Time-Dependent SIR Model for COVID-19 with Undetectable Infected Persons."

Cinelli, Matteo, Walter Quattrociocchi, Alessandro Galeazzi, Carlo Michele Valensise, Emanuele Brugnoli, Ana Lucia Schmidt, Paola Zola, Fabiana Zollo, and Antonio Scala. 2020. "The Covid-19 Social Media Infodemic." ArXiv Preprint ArXiv:2003.05004.

Du Toit, Andrea. 2020. "Outbreak of a Novel Coronavirus." Nature Reviews Microbiology 18 (3): 123-123.

Elmousalami, Haytham H., and Aboul Ella Hassanien. 2020. "Day Level Forecasting for Coronavirus Disease (COVID-19) Spread: Analysis, Modeling and Recommendations." ArXiv Preprint ArXiv:2003.07778.

Evans, Olaniyi. 2020. "Socio-Economic Impacts of Novel Coronavirus: The Policy Solutions." BizEcons Quarterly 7: 3-12.

Fernandes, Nuno. 2020. "Economic Effects of Coronavirus Outbreak (COVID-19) on the World Economy." Available at SSRN 3557504.

Fetzer, Thiemo, Lukas Hensel, Johannes Hermle, and Christopher Roth. 2020. "Coronavirus Perceptions and Economic Anxiety." ArXiv Preprint ArXiv:2003.03848.

Fong, Simon James, Gloria Li, Nilanjan Dey, Ruben Gonzalez Crespo, and Enrique Herrera-Viedma. 2020a. "Composite Monte Carlo Decision Making under High Uncertainty of Novel Coronavirus Epidemic Using Hybridized Deep Learning and Fuzzy Rule Induction." ArXiv Preprint ArXiv:2003.09868.

Fong, Simon James, Gloria Li, Nilanjan Dey, Rubén González Crespo, and Enrique Herrera-Viedma. 2020b. "Finding an Accurate Early Forecasting Model from Small Dataset: A Case of 2019-Ncov Novel Coronavirus Outbreak." ArXiv Preprint ArXiv:2003.10776. 
Gamero, Javier, Juan A. Tamayo, and Juan A. Martinez-Roman. 2020. "Forecast of the Evolution of the Contagious Disease Caused by Novel Coronavirus (2019-NCoV) in China." ArXiv Preprint ArXiv:2002.04739.

Gong, Binlei, Shurui Zhang, Lingran Yuan, and Kevin Z. Chen. 2020. "A Balance Act: Minimizing Economic Loss While Controlling Novel Coronavirus Pneumonia." Journal of Chinese Governance, 1-20.

Hemdan, Ezz El-Din, Marwa A. Shouman, and Mohamed Esmail Karar. 2020. "Covidx-Net: A Framework of Deep Learning Classifiers to Diagnose Covid-19 in x-Ray Images." ArXiv Preprint ArXiv:2003.11055.

Heymann, David L. 2020. "Data Sharing and Outbreaks: Best Practice Exemplified." The Lancet 395 (10223): 469-470.

Jia, Lin, Kewen Li, Yu Jiang, and Xin Guo. 2020. "Prediction and Analysis of Coronavirus Disease 2019." ArXiv Preprint ArXiv:2003.05447.

Kwok, Kin On, Arthur Tang, Vivian WI Wei, Woo Hyun Park, Eng Kiong Yeoh, and Steven Riley. 2019. "Epidemic Models of Contact Tracing: Systematic Review of Transmission Studies of Severe Acute Respiratory Syndrome and Middle East Respiratory Syndrome." Computational and Structural Biotechnology Journal.

Li, Lixiang, Zihang Yang, Zhongkai Dang, Cui Meng, Jingze Huang, HaoTian Meng, Deyu Wang, Guanhua Chen, Jiaxuan Zhang, and Haipeng Peng. 2020. "Propagation Analysis and Prediction of the COVID19." Infectious Disease Modelling 5: 282-292.

Loayza, Norman V., and Steven Pennings. 2020. Macroeconomic Policy in the Time of COVID-19: A Primer for Developing Countries. World Bank.

Ma, Yueling, Yadong Zhao, Jiangtao Liu, Xiaotao He, Bo Wang, Shihua Fu, Jun Yan, Jingping Niu, Ji Zhou, and Bin Luo. 2020. "Effects of Temperature Variation and Humidity on the Death of COVID-19 in Wuhan, China." Science of The Total Environment, 138226.

McKibbin, Warwick J., and Roshen Fernando. 2020. "The Global Macroeconomic Impacts of COVID-19: Seven Scenarios."

Munster, Vincent J., Marion Koopmans, Neeltje van Doremalen, Debby van Riel, and Emmie de Wit. 2020. "A Novel Coronavirus Emerging in China-Key Questions for Impact Assessment." New England Journal of Medicine 382 (8): 692-694.

Narin, Ali, Ceren Kaya, and Ziynet Pamuk. 2020. "Automatic Detection of Coronavirus Disease (COVID-19) Using X-Ray Images and Deep Convolutional Neural Networks." ArXiv Preprint ArXiv:2003.10849.

Nelson, Lorene M., Julia F. Simard, Abiodun Oluyomi, Vanessa Nava, Lisa G. Rosas, Melissa Bondy, and Eleni Linos. 2020. "US Public Concerns About the COVID-19 Pandemic From Results of a Survey Given via Social Media." JAMA Internal Medicine.

Nesteruk, Igor. 2020. "Statistics Based Predictions of Coronavirus 2019-NCoV Spreading in Mainland China." MedRxiv.

Nguyen, Khoa. 2020. "A Coronavirus Outbreak and Sector Stock Returns: The Tale from The First Ten Weeks of Year 2020." Available at SSRN 3559907.

O'Brien, M., K. Moore, and F. McNicholas. 2020. "Social Media Spread During Covid-19: The Pros and Cons of Likes and Shares." Irish Medical Journal 113 (4): 52-52.

Oh, Yujin, Sangjoon Park, and Jong Chul Ye. 2020. "Deep Learning COVID-19 Features on CXR Using Limited Training Data Sets." ArXiv Preprint ArXiv:2004.05758.

Oliveiros, Barbara, Liliana Caramelo, Nuno C. Ferreira, and Francisco Caramelo. 2020. "Role of Temperature and Humidity in the Modulation of the Doubling Time of COVID-19 Cases." MedRxiv.

Prasse, Bastian, Massimo A. Achterberg, Long Ma, and Piet Van Mieghem. 2020. "Network-Based Prediction of the 2019-Ncov Epidemic Outbreak in the Chinese Province Hubei." ArXiv Preprint ArXiv:2002.04482. 
Qin, Lei, Qiang Sun, Yidan Wang, Ke-Fei Wu, Mingchih Chen, Ben-Chang Shia, and Szu-Yuan Wu. 2020. "Prediction of Number of Cases of 2019 Novel Coronavirus (COVID-19) Using Social Media Search Index." International Journal of Environmental Research and Public Health 17 (7): 2365.

Rajinikanth, V., Nilanjan Dey, Alex Noel Joseph Raj, Aboul Ella Hassanien, K. C. Santosh, and N. Raja. 2020. "Harmony-Search and Otsu Based System for Coronavirus Disease (COVID-19) Detection Using Lung CT Scan Images." ArXiv Preprint ArXiv:2004.03431.

Reperant, Leslie A., and Albert DME Osterhaus. 2017. "AIDS, Avian Flu, SARS, MERS, Ebola, Zika... What Next?" Vaccine 35 (35): 4470-4474.

Reyad, Omar. 2020. "Novel Coronavirus COVID-19 Strike on Arab Countries and Territories: A Situation Report I." ArXiv Preprint ArXiv:2003.09501.

Saire, Josimar E. Chire. 2020. "Infoveillance Based on Social Sensors to Analyze the Impact of Covid19 in South American Population." MedRxiv.

Shahid Nadim, Sk, Indrajit Ghosh, and Joydev Chattopadhyay. 2020. "Short-Term Predictions and Prevention Strategies for COVID-2019: A Model Based Study." ArXiv, arXiv-2003.

Shim, Eunha, Amna Tariq, Wongyeong Choi, Yiseul Lee, and Gerardo Chowell. 2020. "Transmission Potential of COVID-19 in South Korea." MedRxiv.

Shokouhi, M. D., Fernando Miralles-Wilhelm, M. D. Anthony Amoroso, and Mohammad M. Sajadi. 2020. "Temperature, Humidity, and Latitude Analysis to Predict Potential Spread and Seasonality for COVID-19."

Toda, Alexis Akira. 2020. "Susceptible-Infected-Recovered (SIR) Dynamics of COVID-19 and Economic Impact." ArXiv Preprint ArXiv:2003.11221.

Tosepu, Ramadhan, Joko Gunawan, Devi Savitri Effendy, Hariati Lestari, Hartati Bahar, and Pitrah Asfian. 2020. "Correlation between Weather and Covid-19 Pandemic in Jakarta, Indonesia." Science of The Total Environment, 138436.

Wang, Jingyuan, Ke Tang, Kai Feng, and Weifeng Lv. 2020. "High Temperature and High Humidity Reduce the Transmission of Covid-19." Available at SSRN 3551767.

Wang, Shuai, Bo Kang, Jinlu Ma, Xianjun Zeng, Mingming Xiao, Jia Guo, Mengjiao Cai, Jingyi Yang, Yaodong $\mathrm{Li}$, and Xiangfei Meng. 2020. "A Deep Learning Algorithm Using CT Images to Screen for Corona Virus Disease (COVID-19)." MedRxiv.

Wu, Yu-Huan, Shang-Hua Gao, Jie Mei, Jun Xu, Deng-Ping Fan, Chao-Wei Zhao, and Ming-Ming Cheng. 2020. "JCS: An Explainable COVID-19 Diagnosis System by Joint Classification and Segmentation." ArXiv Preprint ArXiv:2004.07054.

Yilmazkuday, Hakan. 2020. "Coronavirus Disease 2019 and the Global Economy." Available at SSRN 3554381.

Zheng, YANG, YUAN Zi-xia, and J. I. A. Zu-yao. 2020. "Estimating the Number of People Infected with COVID-19 in Wuhan Based on Migration Data." 电子科技大学学报 49: 1-9.

Zhong, Linhao, Lin Mu, Jing Li, Jiaying Wang, Zhe Yin, and Darong Liu. 2020. "Early Prediction of the 2019 Novel Coronavirus Outbreak in the Mainland China Based on Simple Mathematical Model." IEEE Access. 